\title{
PERKEMBANGAN DAERAH PERMUKIMAN PADA KECAMATAN ILIR TIMUR II KOTA PALEMBANG PADA TAHUN 1991-2013
}

\author{
Yeani Rismayanti ${ }^{1}$, Indra Yustian ${ }^{2}$, A.Halim PKS $^{3}$ \\ ${ }^{1-3}$ Program Magister Pengelolaan Lingkungan Universitas Sriwijaya \\ Program Pascasarjana Universitas Sriwijaya \\ ( $\Xi$ ) yeani.peppy@gmail.com
}

\begin{abstract}
ABSTRAK
Kota Palembang merupakan daerah yang sebagian besar terbentuk atas lahan rawa yang hampir tergenang air sepanjang tahun. Pada awalnya budaya bermukim masyarakat Palembang dipengaruhi oleh keberadaan sungai, tanah lunak, dan daerah rawa pasang surut membentuk pola dua inti permukiman yang berkembang dari interaksi masyarakat pribumi di bagian utara sungai dan pendatang di bagian selatan sungai. Semakin meningkatnya jumlah penduduk dan semakin intensifnya aktivitas penduduk di suatu tempat berdampak pada makin meningkatnya perubahan penggunaan lahan. Dalam prakteknya, perubahan fungsi lahan ruang terbuka seperti lahan rawa dan tegalan akan berubah menjadi lahan permukiman. Selain membutuhkan lahan, perkembangan permukiman juga membutuhkan sarana prasarana guna memenuhi kebutuhan masyarakat. Penelitian ini bertujuan untuk menganalisis perkembangan permukiman pada Kecamatan Ilir Timur II Kota Palembang pada tahun 1991-2013. Metode penelitian yang dilakukan dalam penelitian ini adalah dengan menggunakan metode Deskriptif. Data yang digunakan meliputi data sekunder. Analisis data spasial digunakan untuk menganalisa perkembangan permukiman di Kecamatan Ilir Timur II. Hasil penelitian menunjukkan bahwa perkembangan permukiman di Kecamatan Ilir Timur II Pada tahun 1991 hingga tahun 2013, pola permukiman di Kecamatan Ilir Timur II menyebar ke segala arah mengisi ruang terbuka untuk dibangun permukiman. Besaran luas permukiman di Kecamatan Ilir Timur II adalah 927,21 Ha pada tahun 1991 dan pada tahun 2013 luas permukiman menjadi 1.311,38 Ha. Berbeda dengan lahan rawa justru mengalami penurunan hingga $81,8 \%$ sejak tahun 1991. Saat ini lahan rawa yang tersisa sebesar 20,7 Ha.
\end{abstract}

Kata Kunci : Lahan, Perkembangan Permukiman, Perubahan Penggunaan Lahan

\section{PENDAHULUAN}

Pertumbuhan dan perkembangan kota yang terjadi secara alami dapat berdampak positif selama pertumbuhan dan perkembangan kota itu diiringi dengan manajemen dan pengelolaan kota yang baik. Artinya bahwa pengelola kota mengalokasikan sumberdaya, menyediakan sarana dan prasarana, utilitas dan fasilitas kota sesuai dengan kebutuhan masyarakat dan pertumbuhan kota itu sendiri. Di sisi lain, jika tidak dilaksanakan, maka pertumbuhan dan perkembangan kota itu tidak akan berjalan dengan baik dan efisien. Apalagi jika ditinjau dari sisi ekonomi kota, efisiensi dan efektifitas Kota sebagai pusat pelayanan dan jasa tidak dapat terwujud (Yoelianto, 2005).

Menurut Widodo dalam Wicaksono (2003), budaya bermukim masyarakat Palembang pada awalnya sangat dipengaruhi oleh keberadaan sungai, tanah lunak, dan daerah rawa pasang surut, di mana interaksi masyarakat pribumi di bagian utara sungai dan pendatang di bagian selatan sungai membentuk pola dua inti permukiman yang berkembang secara baik. Namun pembangunan kota yang terkonsentrasi di kawasan Seberang Ilir, terjadinya urbanisasi, dan dijadikannya daerah rawa di Seberang Ulu sebagai daerah tangkapan air (tidak terbangun). Dalam masa berikutnya, 
perkembangan cenderung lebih mengarah ke Seberang Ilir, sedangkan kawasan Seberang Ulu perkembangannya semakin tertinggal, tumbuh tanpa kendali, tanpa jaringan infrastruktur kota yang memadai. Jembatan Ampera yang dibangun tahun 1962 yang menyatukan sisi utara (Seberang Ilir) dan sisi selatan (Seberang Ulu) dari dua permukiman yang terpisah selama berabad-abad itu justru semakin mempercepat pergerakan berbagai aktivitas dari selatan ke utara. Bagian utara semakin berkembang dan bagian selatan semakin tertinggal.

Semakin meningkatnya perkembangan pembangunan fisik maka semakin meningkat pula perubahan penggunaan lahan. Kota Palembang sendiri merupakan daerah yang sebagian besar terbentuk atas lahan rawa yang hampir tergenang air sepanjang tahun. Berdasarkan latar belakang di atas, maka diperlukan penelitian mengenai perkembangan daerah permukiman di Kecamatan Ilir Timur II. Penelitian ini diharapkan dapat memberikan penjelasan mengenai arah perkembangan permukiman Kecamatan Ilir Timur II dari tahun 1991 hingga tahun 2013.

Rumusan masalah dalam penelitian ini adalah bagaimana arah perkembangan permukiman pada Kecamatan Ilir Timur II Kota Palembang pada tahun 1991 - 2013? Penelitian ini bertujuan untuk menganalisis arah perkembangan permukiman pada Kecamatan Ilir Timur II Kota Palembang pada tahun 1991-2013.

Secara geografis, Vink dalam Ritohardoyo (2013) berpendapat bahwa lahan adalah suatu wilayah tertentu di atas permukaan bumi, khususnya meliputi semua benda penyusun biosfer yang dapat dianggap bersifat menetap atau berpindah berada di atas wilayah atmosfer, dan di bawah wilayah tersebut mencakup tanah, batuan (bahan) induk, topografi, air, tumbuh-tumbuhan dan binatang, dan berbagai akibat kegiatan manusia pada masa lalu maupun sekarang, yang semuanya memiliki pengaruh nyata terhadap penggunaan lahan oleh manusia, pada masa sekarang maupun masa yang akan datang.

Definisi mengenai penggunaan lahan juga dikemukakan oleh Malingreau dalam Ritohardoyo
(2013). Malingreau berpendapat bahwa penggunaan lahan adalah segala macam campur tangan manusia, baik secara menetap ataupun berpindah-pindah terhadap suatu kelompok sumber daya alam dan sumber daya buatan, yang secara keseluruhan disebut lahan, dengan tujuan untuk mencukupi kebutuhan baik material maupun spiritual, ataupun kebutuhan kedua-duanya.

Menurut Undang-undang No.1 Tahun 2011, permukiman adalah bagian dari lingkungan hunian yang terdiri atas lebih dari satu satuan perumahan yang mempunyai prasarana, sarana, utilitas umum, serta mempunyai penunjang kegiatan fungsi lain di kawasan perkotaan atau kawasan perdesaan. Sedangkan menurut Standar Nasional Indonesia (SNI) 03-1733-2004 mengenai tata cara perencanaan lingkungan perumahan di perkotaan, yang dimaksud permukiman adalah bagian dari lingkungan hidup di luar kawasan lindung, baik yang berupa kawasan perkotaan maupun perdesaan yang berfungsi sebagai lingkungan tempat tinggal atau lingkungan hunian dan tempat kegiatan yang mendukung perikehidupan dan penghidupan.

Peningkatan jumlah penduduk kota selalu diikuti dengan peningkatan tuntutan kebutuhan akan daerah permukiman. Penambahan lahan permukiman tersebut dapat terjadi menjadi tiga gerakan, yakni sentrifugal, sentripetal, dan gerakan lateral, yang kesemuanya mengarah ke sasaran daerah sekitar kota sehingga dapat mempengaruhi perkembangan fisik kota yang terwujud pada pola perubahan pemanfaatan lahan, proses perubahan pemanfaatan lahan, dan dampak perubahan pemanfaatan lahan (Ritohardoyo, 2013).

Penyelenggaraan kawasan permukiman dilakukan untuk mewujudkan wilayah yang berfungsi sebagai lingkungan hunian dan tempat kegiatan yang mendukung perikehidupan dan penghidupan yang terencana, menyeluruh, terpadu, dan berkelanjutan sesuai dengan rencana tata ruang. Herbert (1973) dalam Yunus (2010), mengemukakan teori konsentris mengenai permukiman

"Sejalan dengan perkembangan masyarkat maka berkembang pula jumlah penduduk dan jumlah struktur yang dibutuhkan 
masyarakat dalam menunjang kehidupannya. Sementara itu proses segregasi dan diferensiasi terus berjalan, yang kuat akan selalu mengalahkan yang lemah. Daerah permukiman dan institusi akan terdepak keluar secara "centrifugal" dan "business" akan semakin terkonsentrasi pada lahan yang paling baik di kota"

Abdullah (2000) membagi pola permukiman menjadi dua, yaitu:

1) pola permukiman mengumpul (compact settlement). Pola ini dapat berbentuk radial, linier, dan papan catur

2) pola permukiman menyebar (scattered, dispersed). Pola permukiman ini dapat berbentuk multi pusat dan tersebar murni.

\section{METODOLOGI PENELITIAN}

Penelitian dilaksanakan di Kecamatan Ilir Timur II. Kecamatan Ilir Timur II merupakan salah satu kecamatan di Kota Palembang. Kecamatan Ilir Timur II adalah kecamatan dengan jumlah kelurahan terbanyak di kota Palembang, yaitu terdapat 12 Kelurahan yakni Kelurahan 10 Ilir, Kuto batu, Lawang Kidul, 3 Ilir, 1 Ilir, Sungai Buah, 2 Ilir, 5 Ilir, Duku, 9 Ilir, dan 8 Ilir.

Metode penelitian yang dilakukan dalam penelitian ini adalah dengan menggunakan metode Deskriptif. Metode deskriptif ini merupakan metode yang digunakan untuk menggambarkan secara lengkap mengenai fenomena melalui sejumlah variabel yang berkaitan dengan permasalahan yang diteliti (Sugiyono,2015).

Tahapan penelitian dibagi menjadi dua kegiatan, yaitu mengkaji kajian literatur serta mengkaji data spasial. Pengkajian literatur dibutuhkan untuk menghubungkan antara teori yang digunakan agar sesuai dengan tujuan penelitian. Pada kegiatan kajian literatur berisi tentang definisi permasalahan, objek penelitian. Sedangkan pada kegiatan kedua yaitu mengkaji data spasial, kegiatan yang dilakukan adalah mengolah data peta RBI tahun 1991, dan tahun 2013, kemudian dilanjutkan dengan mengolah data daerah permukiman pada masing-masing tahun tersebut.
Data yang digunakan dalam penelitian ini adalah data sekunder. Data sekunder merupakan data yang diperoleh dari instansi terkait maupun dari sumber lain yang relevan dengan penelitian. Data yang digunakan yaitu Peta rupa bumi, peta blok bangunan, dan peta penggunaan lahan dan ruang Kota Palembang.

Analisis data spasial digunakan untuk menganalisa perkembangan permukiman di Kecamatan Ilir Timur II. Langkah awal dalam analisis spasial ini adalah data penggunaan lahan tahun 1991 ditumpangsusunkan (overlay) dengan peta blok bangunan tahun 2013. Dari hasil overlay tersebut maka dapat diketahui arah perkembangan permukiman di Kecamatan Ilir Timur II.

\section{HASIL dan PEMBAHASAN}

\section{A. Daerah Permukiman di Kecamatan Ilir Timur II Tahun 1991}

Menurut Peraturan Pemerintah Republik Indonesia Nomor 23 Tahun 1988 tentang Perubahan Batas Wilayah Kabupaten Daerah Tingkat II Palembang, dan Kabupaten Daerah Tingkat II Musi Banyuasin dan Kabupaten Daerah Tingkat II Ogan Komering Ilir, menyebutkan bahwa wilayah Kecamatan Ilir Timur II terdiri dari 11 Kelurahan, yakni Kelurahan Sungai Selincah. Kelurahan 1 Ilir, Kelurahan 2 Ilir, Kelurahan 3 Ilir, Kelurahan 5 Ilir, Kelurahan 8 Ilir, Kelurahan 9 Ilir, Kelurahan 10 Ilir, Kelurahan 11 Ilir, Kelurahan Sungai Buah, dan Kelurahan Bukit Sangkal.

Pada tahun 1991, daerah permukiman menyebar di seluruh wilayah Kecamatan Ilir Timur II. Penggunaan lahan dapat dilihat pada tabel 4. Berikut.

Tabel 1. Luas lahan di Kecamatan Ilir Timur II tahun 1991

\begin{tabular}{llll}
\hline No. & Jenis Lahan & $\begin{array}{l}\text { Luas } \\
\text { (Ha) }\end{array}$ & $\begin{array}{l}\text { Persentase } \\
\text { Luasan }\end{array}$ \\
\hline 1. & Permukiman & 927,21 & 36,24 \\
\hline 2. & Rawa & 114,33 & 4,46 \\
\hline 3. & Tegalan & 369,98 & 14,46 \\
\hline
\end{tabular}

Sumber : Hasil olah data peta RBI tahun 1991 
Berdasarkan tabel 1. diketahui bahwa diketahui bahwa jumlah luas lahan terbangun pada tahun 1991 sebesar 927,21 $\mathrm{Ha}$ atau 36,24\% dari keseluruhan luas wilayah Kecamatan Ilir Timur II. sedangkan luas tegalan sebesar 369,98 Ha dan luas rawa 114,33 Ha. Berikut ini adalah gambaran luasan permukiman di Kecamatan Ilir Timur II Tahun 1991

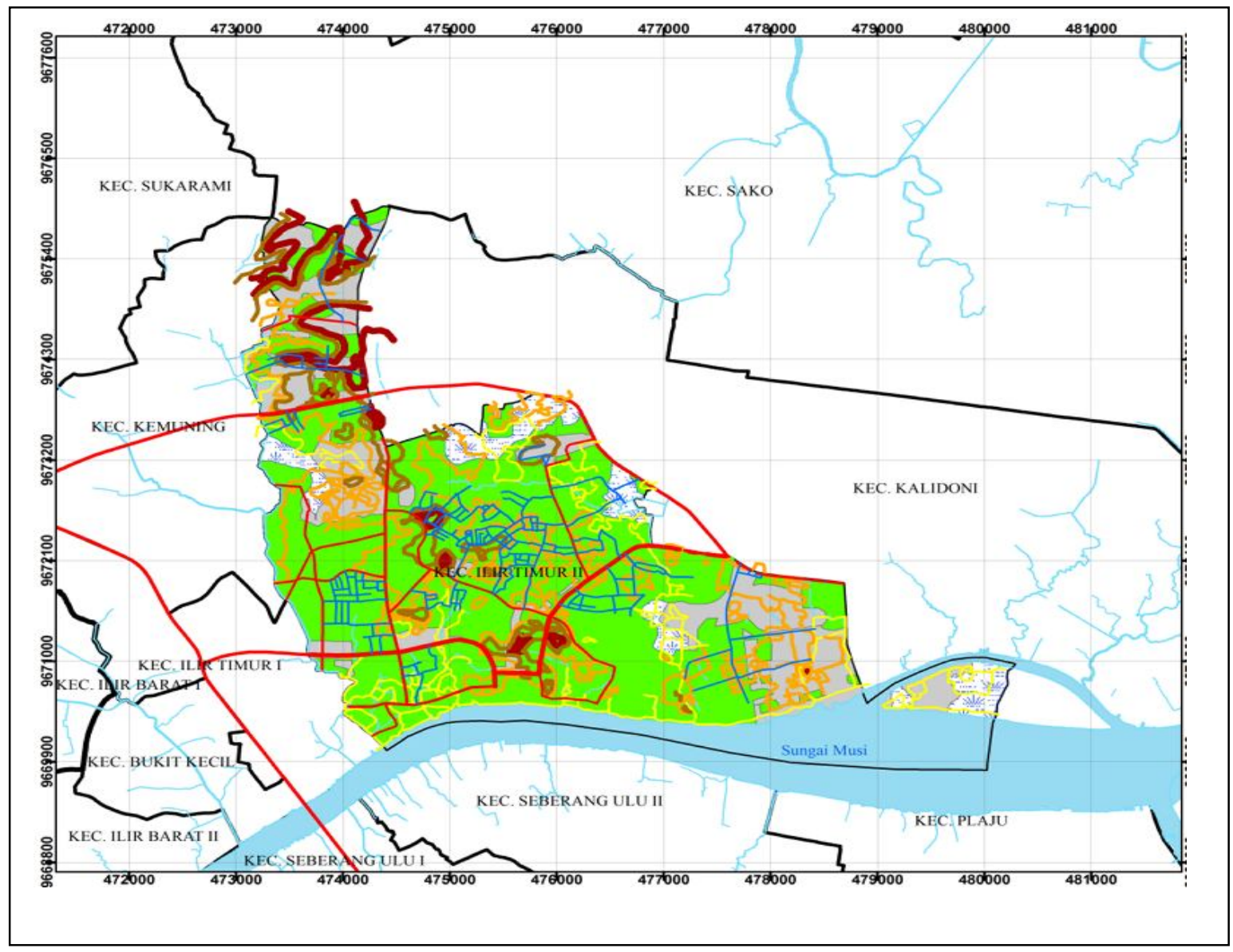

Gambar 1. Peta Luasan permukiman di Kecamatan Ilir Timur II Tahun 1991

\section{B. Daerah Permukiman di Kecamatan Ilir Timur II Tahun 2013}

Berdasarkan Peraturan Daerah Kota Palembang Tahun 2000 tentang Pemekaran Kecamatan, menyebutkan bahwa pada pasal 3, di dalam wilayah Kecamatan Ilir Timur II berubah menjadi 12 Kelurahan yakni Kelurahan 1 Ilir, Kelurahan 2 Ilir, Kelurahan 3 Ilir, Kelurahan 5 Ilir, Kelurahan 8 Ilir, Kelurahan 9 Ilir, Kelurahan 10 Ilir, Kelurahan 11 Ilir, Kelurahan Sungai Buah, Kelurahan Lawang Kidul, Kelurahan Duku dan Kelurahan Kuto Batu.

Pada tahun 2013 menunjukkan bahwa hampir seluruh wilayah kecamatan tersebut telah beralih fungsi menjadi daerah permukiman. Luas daerah permukiman dan lahan rawa serta tegalan mengalami perubahan. Berikut ini adalah luas lahan daerah permukiman, rawa dan tegalan di Kecamatan Ilir Timur II Tahun 2013.

Tabel 2. Penggunaan Lahan di Kecamatan Ilir Timur II tahun 2013

\begin{tabular}{lll}
\hline No. & Jenis Lahan & Luas $(\mathrm{Ha})$ \\
\hline 1. & Permukiman & 1311,38 \\
\hline 2. & Rawa & 20,7 \\
\hline 3. & Tegalan & 218,58 \\
\hline \multicolumn{3}{r}{ Sumber : Olah data peta tahun 2013}
\end{tabular}

Berdasarkan tabel di atas, diketahui bahwa luas lahan permukiman sebesar 1311,38 $\mathrm{Ha}$, luas lahan rawa sebesar 20,7 $\mathrm{Ha}$, dan luas lahan tegalan sebesar 218,58. Ini berarti bahwa daerah permukiman telah menggunakan lahan rawa dan lahan tegalan dalam pembangunannya. 
Meyer dan Turner dalam Meiliyani (2008) menjelaskan bahwa perubahan pada penutupan lahan adalah perubahan keanekaragaman biotik, produktivitas yang utama dan aktual, kualitas tanah, aliran permukaan, serta kecepatan sedimentasi. Hingga tahun 2013, luas permukiman di wilayah Kecamatan Ilir Timur II tercatat sebesar $1.311,38$ Ha. Berikut ini adalah gambaran perubahan Perkembangan luas permukiman pada wilayah Kecamatan Ilir Timur II.

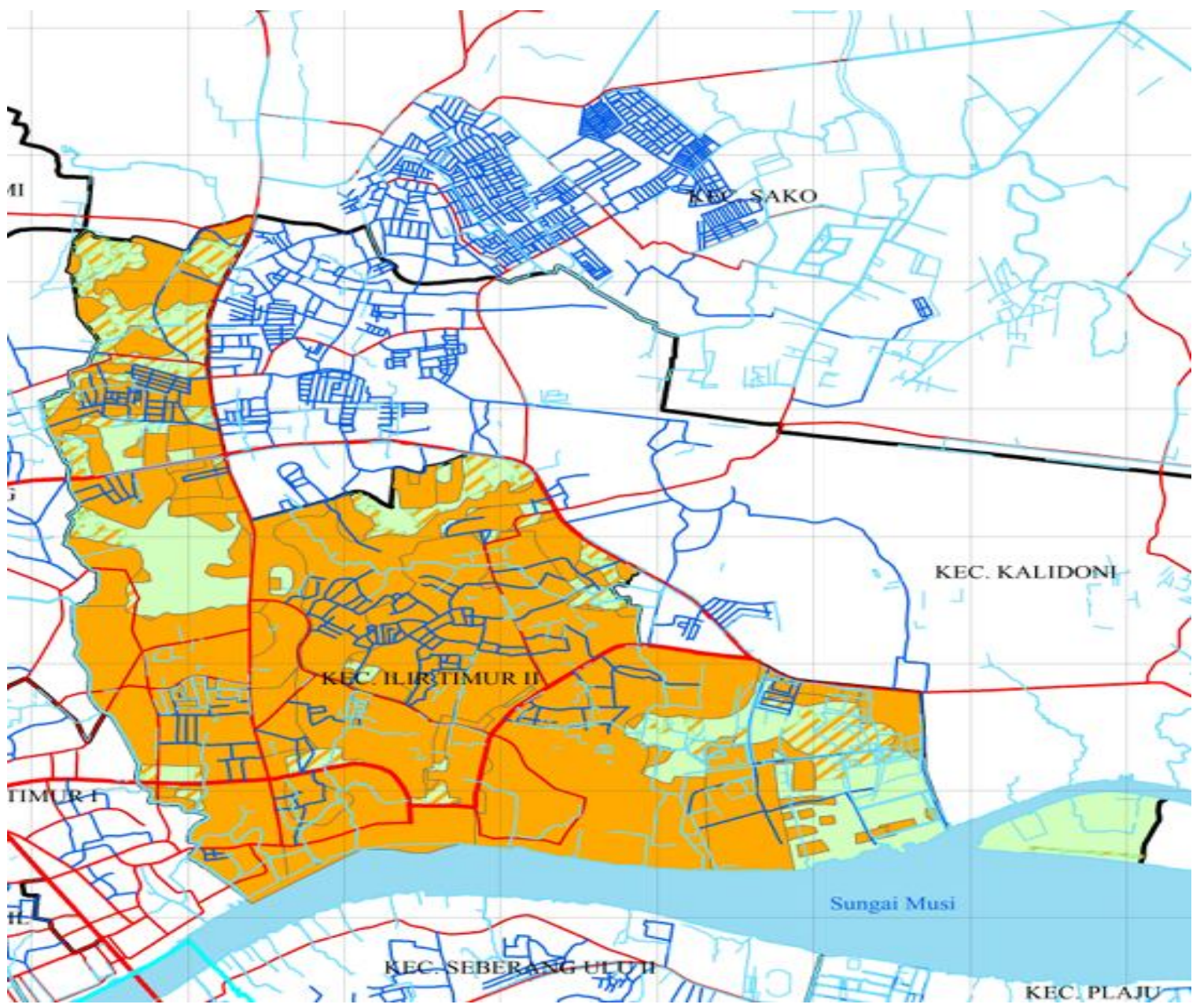

Gambar2. Luas Perubahan Permukiman dari Tahun 1991-2013

Dari gambar di atas diketahui bahwa pada tahun 2013 permukiman penduduk memiliki pola menyebar ke arah ruang terbuka atau ke arah lahan terbuka yang belum dibangun. Hal ini meyebabkan adanya perubahan penggunaan lahan. Perubahan penggunaan lahan yang terjadi mengakibatkan fungsi hilangnya fungsi lahan sebelumnya. Rawa merupakan lahan genangan air secara terus menerus atau musiman yang terjadi secara alami akibat drainase alami. Rawa berfungsi sebagai sumber air, tampungan air dan merupakan sistem pengendali banjir. sehingga apabila lahan tersebut berganti, maka fungsinya pun akan berganti.

\section{SIMPULAN}

Luas permukiman di wilayah Kecamatan Ilir Timur II tercatat sebesar 1.311,38 Ha. Hal ini berarti bahwa luas tersebut mengalami penambahan sebesar $50,21 \%$ dari luas permukiman pada tahun 1991. Peningkatan luas lahan permukiman ini tidak sebanding dengan peningkatan lahan rawa. Sebab pada tahun 2013, lahan rawa justru mengalami penurunan hingga $81,8 \%$ dari tahun 1991. Saat ini lahan rawa yang tersisa sebesar 20,7 Ha.

Perkembangan permukiman tidak hanya mengenai cakupan luasan suatu daerah maupun 
jumlah penduduk yang mendiaminya, tetapi dalam perkembangan wilayah harus memperhatikan kondisi sarana prasarana guna menunjang penghidupan. Oleh karena itu, sangat diperlukan pertimbangan-pertimbangan yang berkaitan dengan kualitas lingkungan dalam perkembangannya. Sebab dampak yang ditimbulkan seringkali tidak terjadi pada saat itu tetapi dapat terjadi di waktu yang akan datang. Selain itu, sikap tegas dari masing-masing pemimpin unit wilayah sangat diperlukan, hal ini berguna untuk meningkatkan kesadaran dan kepedulian warganya terhadap lingkungan permukimannya.

Direkomendasikan kepada pemerintah harus memperhatikan pola pengembangan tata ruang wilayah terutama mengenai pembangunan perumahan dan permukiman penduduk. Hal ini perlu dilakukan agar tidak terjadi penurunan daya dukung lingkungan maupun kualitas lingkungan. Perlu ada tinjauan mengenai pembangunan permukiman secara vertikal, mengingat semakin sedikitnya lahan ruang terbuka di Kecamatan Ilir Timur II. Bagi peneliti, perlu adanya penelitian lanjutan mengenai upaya penanggulangan dampak yang ditimbulkan dari adanya perkembangan permukiman baik dampak secara fisik maupun non fisik serta penelitian mengenai Ruang Terbuka Hijau (RTH) di Kecamatan Ilir Timur II.

\section{DAFTAR PUSTAKA}

Abdullah. 2000. Upaya Meningkatkan Income Penduduk Kawasan Penyangga Kota Melalui Penataan Prasarana Permukiman. laporan penelitian. Lemlit Universitas Tadulako. Palu

Meiliyani, 2008. Identifikasi Perubahan Penggunaan dan Penutupan Lahan di Kota Palembang dari Zaman Klasik hingga Kemerdekaan (6832007). Skripsi. Program Studi Arsitektur Lanskap Institut Pertanian Bogor

Peraturan Daerah Kota Palembang Nomor 23b Tahun 2000 Tentang Pemekaran Kecamatan

Peraturan Pemerintah Republik Indonesia Nomor 23 Tahun 1988 Tentang Perubahan Batas Wilayah Kabupaten Daerah Tingkat II Palembang, dan Kabupaten daerah Tingkat II Musi Banyuasin dan Kabupaten Daerah Tingkat II Ogan Komering Ilir.

Ritohardoyo, S., 2013. Penggunaan dan Tata Guna Lahan. Yogyakarta: Penerbit Ombak

Sugiyono. 2015. Metode Penelitian Pendidikan (Pendekatan Kuantitatif, Kualitatif dan R\&D). Penerbit CV. Alfabeta: Bandung.

Undang-undang No 1 Tahun 2011 Tentang penyelenggaraan kawasan Permukiman

Wicaksono, B. 2003. Kajian Pengembangan Kawasan Seberang Ulu Sebagai Arahan Pengembangan Kota Palembang Bagian Selatan. Tesis. Program Pascasarjana Magister Teknik Pembangunan Kota Universitas Diponegoro: Semarang.

Yoelianto, B. 2005. Kajian Spasial Perkembangan Kota Purwodadi. Tesis. Magister Teknik Pembangunan Wilayah Dan Kota Program Pascasarjana Universitas Diponegoro: Semarang.

Yunus, H.S. 2010. Metodologi Wilayah Kontemporer Yogyakarta: Pustaka Pelajar. 